\title{
THE EFFECT OF LEADERSHIP TOWARD EMPLOYEES' JOB SATISFACTION IN QUALITY CONTROL DIVISION OF PT X PADALARANG
}

\author{
Yulia Listianti ${ }^{1}$; Arif Yusuf Hamali ${ }^{2}$ \\ Politeknik PIKSI Ganesha Bandung \\ Jln. Jend. Gatot Subroto 301, Bandung, Jawa Barat, Indonesia 40274 \\ yulialistianti@gmail.com ${ }^{1}$, arifyusufhamali@yahoo.co.id ${ }^{2}$
}

\begin{abstract}
This research was conducted at Quality Control Division of PT X Padalarang, aimed to determine correlation leadership and job satisfaction, and also to analyze the effect of leadership on job satisfaction at Quality Control Division of PT X Padalarang. Respondents of this research are 52 people selected with simple random sampling technique. The method used is descriptive and associative, which tests the connection using the Spearman rank correlation analysis, and also done to determine the accuracy of measurement using by the validity and reliability test. Results of the validity and reliability test of variables $X$ and $Y$ are valid and reliable. Calculations were performed using SPSS software ver. 19. The result of this study showed that leadership is in the category of good and job satisfaction is in the category of good. Results showed the correlation of leadership with job satisfaction at Quality Control Division of PT X Padalarang with correlation coefficient = 0,679. Based on the criteria champion, this relationship is in the criteria of strong relationship. Results of this calculation showed the coefficient of determination $=46,10 \%$. It showed that the hypothesis is proved, that there is an influence of leadership to job satisfaction at Quality Control Division of PT X Padalarang.
\end{abstract}

Keywords: leadership, job satisfaction, champion criteria

\begin{abstract}
ABSTRAK
Penelitian ini dilakukan di divisi Quality Control PT X Padalarang, yang bertujuan untuk menentukan korelasi antara kepemimpinan dan kepuasan kerja, dan juga untuk menganalisis pengaruh kepemimpinan terhadap kepuasan kerja di divisi Quality Control PT X Padalarang. Responden dari penelitian ini adalah 52 orang yang dipilih dengan teknik sampling acak. Metode yang digunakan adalah deskriptif dan asosiatif, yang menguji koneksi menggunakan analisis the Spearman rank correlation, dan juga dilakukan untuk menentukan akurasi pengukuran dengan menggunakan uji validitas dan reliabilitas. Hasil uji validitas dan reliabilitas variabel $X$ dan $Y$ adalah valid dan reliabel. Perhitungan dilakukan dengan menggunakan software SPSS ver. 19. Hasil penelitian ini menunjukkan bahwa kepemimpinan dalam kategori baik dan kepuasan kerja juga dalam kategori baik. Hasil penelitian menunjukkan korelasi kepemimpinan dengan kepuasan kerja di divisi Quality Control PT X Padalarang dengan koefisien korelasi $=0.679$. Berdasarkan kriteria juara, hubungan ini berada pada kriteria hubungan yang kuat. Hasil perhitungan menunjukkan koefisien determinasi $=46,10 \%$. Hal ini menunjukkan bahwa hipotesis terbukti, bahwa ada pengaruh kepemimpinan terhadap kepuasan kerja di divisi Quality Control PT X Padalarang.
\end{abstract}

Kata kunci: kepemimpinan, kepuasan kerja, kriteria juara 


\section{INTRODUCTION}

Leadership in an organization has a very important role because of its presence; there can be a process of helping and supporting the others to work hard to achieve their goal. Leadership can affect the morale and job satisfaction, security, job quality and the achievement of an organization. One of the elements that differentiate between a leader and a non-leader is the ability to visualize how an organization will be developed in the future by noticing several developments happening in the environment outside of the organization. Leadership contains contextual meaning such as (Solihin, 2009): (1) having directing character, which is directing people who are leaded to achieve the goal; (2) having affecting character, which is a leader must be able to change the characteristic of subordinate, colleague, and even superior, by words, characteristic and action, so those parties can cooperate in the process of achieving the goal; and (3) having authority, which is the right owned by a leader to order people (subordinate) in activities related to work or task.

Leadership is a process of directing and affecting activity related to the work of the group member (Sopiah, 2008). The dimensions that can be used to measure whether the leadership in a company effective or not consist of: (1) task function, which is related to something which must be done to choose and achieve goals rationally; and (2) maintenance function, which is related to the emotional satisfaction used to develop and maintain group, society or for existence of organization.

Study about job satisfaction is one of important factors in study of organizational behavior. Job satisfaction is focused on employees' character toward the work which contains three important dimensions (Kondalkar, 2007): (1) job satisfaction can be measured through emotional response on situation that cannot be seen but can be predicted; (2) job satisfaction is related to reward or hope expected by employees; (3) job satisfaction related to job condition, such as workload, remuneration, attitude toward subordinate, and opportunity for improvement.

Basically job satisfaction reflects someone's feeling toward the work, shown from employees' positive character toward the job and all things faced in work environment. Satisfied employees like their work situation more than unsatisfied employees, who do not like it. Job satisfaction can be defined as character (positive) of employees on their work, which is appeared based on assessment on the work situation. Satisfied employees like their work situation more than unsatisfied employees who do not like their work situation (Umam, 2012). The dimensions that can be used to measure whether the leadership in a company effective or not consist of fair salary/reward, supporting work condition and work relationship.

Previous researches stated that leadership affected job satisfaction positively and significantly (Ruvendi, 2005; Kaihatu dan Rini, 2007; Darwito, 2008; Lahar, 2008; Purnomo dan Cholil, 2010; Baihaqi, 2010; Nugraha, 2011; Wilar, 2011; Fadli, dkk, 2012; Pratama, 2012; Djestawana, 2012; Nurfaiyah dan Damajanti, 2012; Siregar, 2012; Alam, 2013; Kristian, 2013). Previous research from Lasya (2013) and Saputra (2013) stated that leadership did not affect job satisfaction directly and significantly.

Quality Control division of PT X Padalarang is a company moved in textile industry, located in industry sector Batujajar Permai, Padalarang, Jawa Barat. Phenomena of leadership happened in Quality Control division of PT X Padalarang is that existing leader has not perform the function of leadership effectively. The existing leader is considered as not being able to perform the tasks of leadership well in building work relationship with the subordinates. That phenomenon can be seen explicitly in Table 1. 
Table 1 Opinion of 30 Employees in Quality Control Division of PT X Padalarang about Leadership

\begin{tabular}{llcc}
\hline No. & \multicolumn{1}{c}{ Employees' opinion } & $\begin{array}{c}\text { Opinion } \\
\text { (Yes) }\end{array}$ & $\begin{array}{c}\text { Opinion } \\
\text { (No) }\end{array}$ \\
\hline 1. & Leader gives direction for employees in work & -- & $\sqrt{ }$ \\
2. & Leader encourages employees & -- & $\sqrt{ }$ \\
3. & Leader create harmony work situation & -- & $\sqrt{ }$ \\
4. & Leader can lessen tension or conflict & -- & $\sqrt{ }$ \\
\hline
\end{tabular}

Source: the result of initial interview in Quality Control division of PT X Padalarang (2014)

The phenomenon of job satisfaction happened in Quality Control division of PT X Padalarang is employees, in general, feel unsatisfied in working. The job dissatisfaction experienced by employees can be seen in table 2 .

Table 2 Opinion of 30 Employees in Quality Control Division of PT X Padalarang about Job Satisfaction

\begin{tabular}{|c|c|c|c|}
\hline No. & Employees' opinion & $\begin{array}{c}\text { Opinion } \\
\text { (satisfied) }\end{array}$ & $\begin{array}{c}\text { Opinion } \\
\text { (unsatisfied) }\end{array}$ \\
\hline 1. & Employees' job satisfaction toward the work facility & -- & $\sqrt{ }$ \\
\hline 2. & $\begin{array}{l}\text { Employees' job satisfaction toward work relation between } \\
\text { subordinate and leader }\end{array}$ & -- & $\sqrt{ }$ \\
\hline 3. & Employees' job satisfaction toward direction from leader in work & -- & $\sqrt{ }$ \\
\hline 4. & Employees' job satisfaction toward the incentive allowance & -- & $\sqrt{ }$ \\
\hline
\end{tabular}

Source: the result of initial interview in Quality Control division of PT X Padalarang (2014)

Based on the explanation and data, the problem studied can be formulated. First, it is how the relationship between leadership and employees' job satisfaction in Quality Control division of PT X Padalarang is. Second, whether there is significant effect of leadership on job satisfaction in Quality Control division of PT X Padalarang.

The goal of this research is to find out the relationship between leadership and employees' job satisfaction in Quality Control division of PT X Padalarang. Moreover, this research aims to find out whether there is a significant effect of leadership on job satisfaction in Quality Control division of PT $\mathrm{X}$ Padalarang.

\section{Leadership}

Managerial leadership is defined as a process of directing and affecting activity related to the task of group member (Sopiah, 2008). Three important implications in leadership are: (1) leadership must involve other people, that are subordinate; (2) leadership covers the distribution of different authority between leader and subordinate; and (3) leader other than legally can give order or direction to the subordinates, also must affect the subordinates with many ways.

The dimensions of leadership according to Sopiah (2008) consist of: (1) Task function, is a function related to something that must be done to choose and achieve goals rationally. The indicators of task function analyzed in this research are leader's ability to encourage subordinate, leader's ability to delegate order or authority to subordinate, leader's ability to achieve target delegated by the highest leader; and leader's ability to make job description. (2) Maintenance function is a function related to the emotional satisfaction which is needed to develop and maintain group, society or for organization's existence. The indicators analyzed in this research are: leader's ability to lessen tension 
in workplace, leader's ability to monitor employees' performance, leader's ability to give direction to subordinate, leader's ability to set job standard, leader's ability to create harmony; and leader's ability to solve problem.

\section{Job Satisfaction}

Job satisfaction is defined as the character (positive) of employees on their work, appeared based on assessment on the work situation (Umam, 2012). There are two important elements in job satisfaction: the value of job and basic needs. The values of job are the goals which are achieved in doing work. The value that is wanted to be achieved is the values considered as important by individual.

Umam (2012) States there are factors affecting employees' satisfaction and dissatisfaction in working, like: (1) Fair salary/reward. The indicators analyzed in this research are: employees' job satisfaction toward salary according to workload, employees' job satisfaction toward positional allowance, employees' job satisfaction toward salary according to position; and employees' job satisfaction toward salary according to achievement. (2) Supporting work condition. The indicators analyzed in this research are employees' job satisfaction toward facility, employees' job satisfaction toward direction from leader, and employees' job satisfaction toward workspace. (3) Work relationship. The indicators analyzed in this research are: employees' job satisfaction toward work relationship between leader and subordinate, employees' job satisfaction toward work relationship between leaders, and employees' job satisfaction toward work relationship between subordinates.

\section{Framework}

The framework of this research can be seen in figure 1

Independent Variable (X)

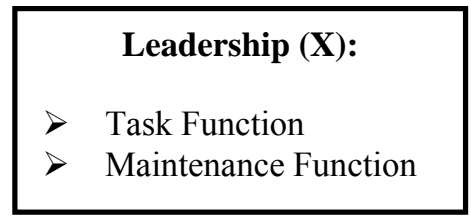

Dependent Variable (Y)

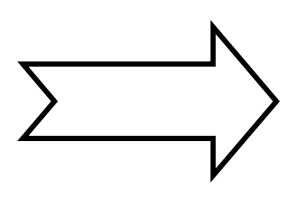

Job Satisfaction (Y):

Fair salary/reward

Supporting work condition

Work relationshin

Figure 1 Framework

\section{Hypothesis}

Based on analysis that has been stated, the research hypothesis can be formulated as it is predicted that leadership affect employees' job satisfaction significantly in Quality Control division of PT X Padalarang.

\section{METHOD}

Research method used in this research is descriptive and associative. Descriptive research basically is a process of generalization of a research result based on one sample and its research variable is independent, so the hypothesis is not in form of comparison or the relation between two variables or more (Sugiyono, 2006). Associative research aims to analyze the relation between 
variables in population through the variable relation data in sample, and the hypothesis is to test the existing correlation coefficient in sample to be applied to all samples taken (Sugiyono, 2006).

Population is generalization of territory consisting of object/subject that have particular quality and characteristic as set by researcher to be studied, and then will be concluded (Sugiyono, 2006). Population of this research is employees in Quality Control division of PT X Padalarang about 107 people. The sample is the amount and characteristic owned by that population (Sugiyono, 2006). The determination of sample uses Slovin's formula in this research, as following:

$$
\mathrm{n}=\frac{\mathrm{N}}{1+\mathrm{N}(\mathrm{e}) 2}
$$

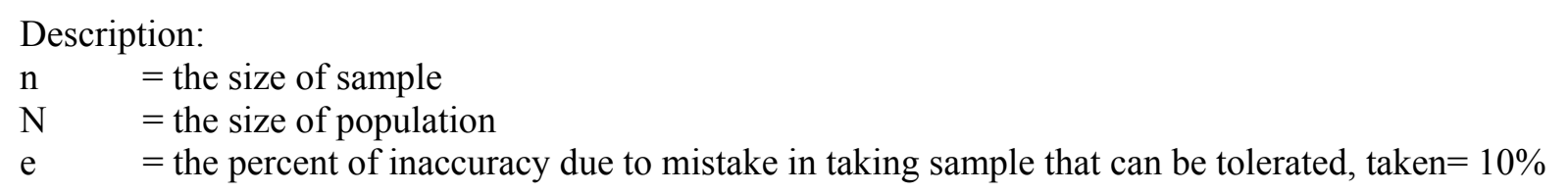

$$
\begin{gathered}
\mathrm{n}=\frac{107}{1+107(0.1) 2} \\
n=\frac{107}{1+1,07}=51,69 \text { rounded to } 52 \text { people }
\end{gathered}
$$

The technique of sampling chosen is simple random sampling, which is a simple random technique because the sampling is done randomly without paying attention to the level in that population, and this is done if the population is considered homogeny (Sugiyono, 2006). Data used in this research is primary source data and secondary data. Primary data is collection of data done directly to the analyzed object to get the answer from the respondents. Secondary data is data obtained from company, literature, and other information which are considered relevant and supporting the research. Method used to collect data is a closed system questionnaire, which means for each question it is provided with the answers. Questionnaire used in this research is Likert scale. The scale is made by gradation from strongly disagree $($ score $=1)$ to strongly agree $($ score $=5)$.

Analysis taken in this research is descriptive and associative. Descriptive analysis uses weighting analysis, and to find the standard weight value can be done by finding the length of weight range. The standard weight value can be determined by finding the length of weight range from five classifications, as following:

$$
\mathrm{R}=\frac{\text { (the highest score } \mathrm{x} \text { the amount of sample) }- \text { (the lowest score } \mathrm{x} \text { amount of sample) }}{5}
$$

$\mathrm{R} \quad=$ the range of classification

$$
\mathrm{R}=\frac{(5 \times 52)-(1 \times 52)}{5} \quad \mathrm{R}=42
$$


The weighting is divided into five levels based on its classification, started from the lowest level $t$ the highest level with weight range 42 . The classification of standard weight value is generated in table 3.

Table 3 The Standard Weight Value

\begin{tabular}{cc} 
Weight value & Category \\
\hline $52-93$ & Worst \\
$94-135$ & Worse \\
$136-177$ & Enough \\
$178-219$ & Good \\
$220-261$ & Best \\
\hline
\end{tabular}

Source: the result of processing primary data

Associative analysis is done to see how the effect of independent variable and dependent variable, in his case, the effect of leadership (X) toward job satisfaction (Y), by using Spearman's rank formula as following:

$$
r_{1}=1-\left[\frac{6 \sum d_{i^{2}}}{N^{3}-N}\right]
$$

$$
\begin{array}{ll}
\mathrm{r}_{1} & =\text { correlation analysis } \\
\mathrm{d}_{\mathrm{i}} & =\text { difference of two variable } \\
\mathrm{N} & =\text { size of sample }
\end{array}
$$

The test of correlation coefficient is done to find out the truth of hypothesis presented in this research by using t-test formula:

$$
t=\sqrt[r]{\frac{N-2}{1-r^{2}}}
$$

$$
\begin{array}{ll}
\mathrm{r} & =\text { correlation coefficient } \\
\mathrm{N} & =\text { size of sample }
\end{array}
$$

t-test is done to prove that leadership variable (independent variable) affects job satisfaction (Y variable) significantly, with provision as following:

If $t_{\text {count }}>t_{\text {tables }}$, then leadership affects job satisfaction significantly, or Ho is rejected and $H_{1}$ is accepted.

If $\mathrm{t}_{\text {count }}<\mathrm{t}_{\text {table, }}$, then leadership does not affect job satisfaction significantly, or Ho is accepted and $\mathrm{H}_{1}$ is rejected. 
The calculation in data analysis in this research uses SPSS Software version 19. The next step is analyzing the correlation to see the effect of leadership on employees' job satisfaction by using Coefficient of Determination with this formula:

$$
K D=r^{2} \times 100 \%
$$

Correlation or cohesion of the relation between free variable and bound variable is classified by Riduwan and Kuncoro (2007)

Table 4 Interpreting Correlation Coefficient of r Value

\begin{tabular}{cc}
\hline Coefficient interval & Level of relation \\
\hline $0,80-1,000$ & Very strong \\
$0,60-0,799$ & Strong \\
$0,40-0,599$ & Strong enough \\
$0,20-0,399$ & Weak \\
$0,00-0,199$ & Very weak \\
\hline Source: Riduwan and Kuncoro (2007)
\end{tabular}

\section{RESULTS AND DISCUSSION}

\section{Validity Test on Research Instrument}

The result of validity test on $\mathrm{X}$ instrument variable is leadership and $\mathrm{Y}$ variable is job satisfaction stating all is valid, based on the criteria if correlation coefficient or $r$ count $>0,3$ with significance degree $5 \%(\alpha=5 \%)$, then the statement is valid. The result of validity test on leadership variable and job satisfaction variable is shown in table 5 and 6.

Table 5 Validity Test for Leadership Variable (X)

\begin{tabular}{lcc}
\hline \multicolumn{1}{c}{ Question } & r count & description \\
\hline Ability to make job description & 0,603 & Valid \\
Ability to achieve target for the highest leader & 0,632 & Valid \\
Ability to delegate order to subordinate & 0.804 & Valid \\
Ability to encourage subordinate & 0,780 & Valid \\
Ability to give direction to subordinate & 0,838 & Valid \\
Ability to keep work culture & 0,663 & Valid \\
Ability to create harmony work atmosphere & 0,790 & Valid \\
Ability to lessen tension or conflict & 0,640 & Valid \\
Ability to solve problem & 0,799 & Valid \\
Ability to evaluate subordinate's performance & 0,750 & Valid \\
\hline
\end{tabular}

Source: the result of processing primary data (2014) 
Table 6 The Result of Validity Test on Job Satisfaction Variable

\begin{tabular}{lcc}
\multicolumn{1}{c}{ Question } & r count & Description \\
\hline Job satisfaction toward positional allowance & 0,631 & Valid \\
Job satisfaction toward punctuality of payment & 0,734 & Valid \\
Job satisfaction toward salary according to work period & 0,680 & Valid \\
Job satisfaction toward salary according to workload & 0,703 & Valid \\
Job satisfaction toward workspace & 0,553 & Valid \\
Job satisfaction toward direction from leader & 0,664 & Valid \\
Job satisfaction toward facility & 0,642 & Valid \\
Job satisfaction toward work relationship between & 0,607 & Valid \\
subordinates & & \\
Job satisfaction toward work relationship with leaders & 0,538 & Valid \\
Job satisfaction toward work relationship between leaders & 0,549 & Valid \\
\hline Sourc: thesult of processing primary data (2014) & &
\end{tabular}

Source: the result of processing primary data (2014)

\section{Reliability Test on Research Instrument}

The result of reliability test on $\mathrm{X}$ instrument variable is leadership and $\mathrm{Y}$ variable is job satisfaction stating all is reliable, based on the assessment criteria on coefficient $\alpha$-Cronbach, if $>$ 0,7 is categorized reliable. The result of reliability test on leadership variable and job satisfaction variable is shown in table 7 and 8 .

Table 7 The Result of Reliability Test on Leadership Variable

\begin{tabular}{|c|c|c|}
\hline \multicolumn{3}{|c|}{ Reliability Statistics } \\
\hline \multirow[t]{2}{*}{ Cronbach's Alpha } & & \\
\hline & .901 & 10 \\
\hline
\end{tabular}

Table 8 The Result Of Reliability Test on Job Satisfaction Variable

\begin{tabular}{lll}
\hline \multicolumn{3}{c}{ Reliability Statistics } \\
\hline Cronbach's Alpha & N of Items & 10 \\
\hline
\end{tabular}

Source: The result of processing primary data (2014)

\section{Descriptive Analysis}

The average descriptive result on respondents' opinion about leadership variable in Quality Control division of PT X Padalarang is in table 9. 
Table 9 Respondents' Opinion about Leadership Variable

\begin{tabular}{|c|c|c|c|c|c|c|c|c|c|}
\hline \multirow{2}{*}{ No } & \multirow{2}{*}{ Dimension } & \multirow{2}{*}{ Indicator } & \multicolumn{5}{|c|}{ Response } & \multirow{2}{*}{ weight } & \multirow{2}{*}{$\begin{array}{c}\text { Average } \\
\text { weight }\end{array}$} \\
\hline & & & 5 & 4 & 3 & 2 & 1 & & \\
\hline \multirow{4}{*}{1} & \multirow{4}{*}{$\begin{array}{l}\text { Task } \\
\text { function }\end{array}$} & $\begin{array}{l}\text { Ability to make job } \\
\text { description }\end{array}$ & 19 & 32 & 1 & 0 & 0 & 226 & \multirow{4}{*}{212} \\
\hline & & $\begin{array}{l}\text { Ability to achieve target for } \\
\text { the highest leader }\end{array}$ & 9 & 39 & 4 & 0 & 0 & 213 & \\
\hline & & $\begin{array}{l}\text { Ability to delegate order to } \\
\text { subordinate }\end{array}$ & 7 & 35 & 10 & 0 & 0 & 205 & \\
\hline & & $\begin{array}{l}>\text { Ability to encourage } \\
\text { subordinate }\end{array}$ & 4 & 38 & 10 & 0 & 0 & 202 & \\
\hline \multirow{6}{*}{2} & \multirow{6}{*}{$\begin{array}{l}\text { Maintenance } \\
\text { function }\end{array}$} & $\begin{array}{l}\text { Ability to give direction to } \\
\text { subordinate }\end{array}$ & 5 & 35 & 11 & 1 & 0 & 200 & \multirow{6}{*}{201} \\
\hline & & $>$ Ability to keep work culture & 2 & 26 & 23 & 1 & 0 & 185 & \\
\hline & & $\begin{array}{l}\text { Ability to create harmony } \\
\text { work atmosphere }\end{array}$ & 9 & 35 & 7 & 1 & 0 & 208 & \\
\hline & & $\begin{array}{l}\text { Ability to lessen tension or } \\
\text { conflict }\end{array}$ & 5 & 40 & 7 & 0 & 0 & 206 & \\
\hline & & $>$ Ability to solve problem & 4 & 41 & 6 & 1 & 0 & 204 & \\
\hline & & $\begin{array}{l}\text { Ability to evaluate } \\
\text { subordinate's performance }\end{array}$ & 2 & 43 & 7 & 0 & 0 & 203 & \\
\hline & Average & & & & & & & & 206 \\
\hline
\end{tabular}

Source: The result of processing primary data (2014)

The average descriptive result on respondents' opinion about job satisfaction variable in Quality Control division of PT X Padalarang is in table 10.

Table 10 Respondents' Opinion about Job Satisfaction Variable

\begin{tabular}{|c|c|c|c|c|c|c|c|c|c|}
\hline \multirow{2}{*}{ No } & \multirow{2}{*}{ Dimension } & \multirow{2}{*}{ Indicator } & \multicolumn{5}{|c|}{ Response } & \multirow{2}{*}{ weight } & \multirow{2}{*}{$\begin{array}{l}\text { Average } \\
\text { weight }\end{array}$} \\
\hline & & & 5 & 4 & 3 & 2 & 1 & & \\
\hline \multirow{4}{*}{1} & \multirow{4}{*}{$\begin{array}{l}\text { Fair } \\
\text { salary/reward }\end{array}$} & $\begin{array}{l}\text { Job satisfaction toward positional } \\
\text { allowance }\end{array}$ & 3 & 27 & 20 & 2 & 0 & 187 & \multirow{4}{*}{197} \\
\hline & & $\begin{array}{l}\text { Job satisfaction toward } \\
\text { punctuality of payment }\end{array}$ & 8 & 29 & 13 & 2 & 0 & 199 & \\
\hline & & $\begin{array}{l}\text { Job satisfaction toward salary } \\
\text { according to work period }\end{array}$ & 8 & 33 & 9 & 2 & 0 & 203 & \\
\hline & & $\begin{array}{l}\text { Job satisfaction toward salary } \\
\text { according to workload }\end{array}$ & 6 & 31 & 14 & 1 & 0 & 198 & \\
\hline \multirow[t]{2}{*}{2} & \multirow{2}{*}{$\begin{array}{l}\text { Supporting } \\
\text { work situation }\end{array}$} & Job satisfaction toward workspace & 14 & 35 & 3 & 0 & 0 & 219 & \multirow{3}{*}{213} \\
\hline & & $\begin{array}{l}\text { Job satisfaction toward direction } \\
\text { from leader }\end{array}$ & 10 & 36 & 6 & 0 & 0 & 212 & \\
\hline \multirow{4}{*}{3} & & Job satisfaction toward facility & 6 & 39 & 7 & 0 & 0 & 207 & \\
\hline & $\begin{array}{l}\text { Work } \\
\text { Relationship }\end{array}$ & $\begin{array}{l}\text { Job satisfaction toward work } \\
\text { relationship between subordinates }\end{array}$ & 7 & 36 & 9 & 0 & 0 & 206 & \multirow{3}{*}{202} \\
\hline & & $\begin{array}{l}\text { Job satisfaction toward work } \\
\text { relationship with leaders }\end{array}$ & 2 & 26 & 24 & 0 & 0 & 186 & \\
\hline & & $\begin{array}{l}\text { Job satisfaction toward work } \\
\text { relationship between leaders }\end{array}$ & 12 & 34 & 5 & 1 & 0 & 213 & \\
\hline
\end{tabular}

Source: The result of processing primary data (2014) 


\section{Associative Analysis}

The effect of leadership toward employees' job satisfaction in Quality Control of PT X Padalarang can be seen by using Spearman's rank correlation analysis. The result of correlation analysis by using SPSS Software version 19 , with $r$ value $=0,679$ is shown in table 11 .

Table 11 Correlation Analysis (Nonparametric Correlations)

\begin{tabular}{|c|c|c|c|c|}
\hline \multicolumn{5}{|c|}{ Correlations } \\
\hline & & & Leadership & Job Satisfaction \\
\hline \multirow{6}{*}{ Spearman's rank } & \multirow{3}{*}{ Leadership } & Correlation Coefficient & 1.000 & $.679^{* *}$ \\
\hline & & Sig. (2-tailed) & & .000 \\
\hline & & $\mathrm{N}$ & 52 & 52 \\
\hline & \multirow{3}{*}{ Job satisfaction } & Correlation Coefficient & $.679^{* *}$ & 1.000 \\
\hline & & Sig. (2-tailed) & .000 & \\
\hline & & $\mathrm{N}$ & 52 & 52 \\
\hline
\end{tabular}

**. Correlation is significant at the 0.01 level (2-tailed).

Source: The result of processing primary data (2014)

The result of SPSS in table 11 shows that the result is significant on significance level $\alpha=5 \%$ (sig. value (2-tailed $=0,000$ is smaller than $5 \%$ ), which means there is an effect of leadership toward job satisfaction significantly in Quality Control division of PT X Padalarang.

The hypothesis test is done to find out the truth of hypothesis presented in this research by using t-test, as following:

Where:

$$
t=\sqrt[r]{\frac{N-2}{1-r^{2}}}
$$

$$
\begin{aligned}
\mathrm{r} & =0,679 \\
\mathrm{~N} & =52
\end{aligned}
$$

So:

$$
\begin{gathered}
t=\sqrt[0,679]{\frac{52-2}{1-(0,679)^{2}}} \\
\mathrm{t}=6,540
\end{gathered}
$$

The value of that $\mathrm{t}$ count is compared to $\mathrm{t}$ table, based on the table of distribution that $\mathrm{t}$ for $\mathrm{db}$ $=52-2=50, \alpha=0,05$. For the test of two parties, it is obtained $t=2,009$. The calculation shows the value of $t$ count is bigger than value of $t$ table which is $6,540>2,009$, then $\mathrm{Ho}$ is rejected and $\mathrm{Ha}$ is accepted. Therefore, the hypothesis presented in this research is right, which is leadership affects employees' job satisfaction significantly in Quality Control division of PT X Padalarang.

Next is to find out the relation level, based on the criteria in table 11 , with $\mathrm{r}$ value $=0,679$, then this relation is in strong relation criteria. From this result $r=0,679$, it is to state the dimension of $\mathrm{X}$ variable (leadership) toward $\mathrm{Y}$ variable (job satisfaction), determined by Coefficient of Determination, as following: 


$$
\begin{gathered}
\mathrm{CD}=\mathrm{r}^{2} \times 100 \% \\
=(0,679)^{2} \times 100 \%=46,10 \%
\end{gathered}
$$

Based on the calculation, with $46,10 \%$, it means this research shows leadership affects job satisfaction about $46,10 \%$, while the rest about $53,90 \%$ is affected by other factors that are not analyzed in this research.

\section{CONCLUSION}

According to the result of the research and explanation, it can be concluded that there is a significant correlation between leadership and job satisfaction in Quality Control division of PT X Padalarang with correlation coefficient $r=0,679$. Based on the Champion criteria with $r$ value -0 , 679, this relation is categorized as strong. From the Coefficient of Determination, it is obtained $\mathrm{r}^{2}=$ 0,4610 , which means leadership affects job satisfaction about $46,10 \%$, while the rest about $53,90 \%$ is affected by other factors that are not analyzed in this research. The result of hypothesis test using t-test shows value of $t$ count is bigger than value of $t$ table $(6,540>2,009)$, thus Ho is rejected and $\mathrm{Ha}$ is accepted. Those results approve the hypothesis in this research that there is positive effect of leadership toward employees' job satisfaction in Quality Control division of PT X Padalarang.

The suggestions that can be given in this research to the management of PT X Padalarang are, first, the existing leader should give clear direction to the employees so they can do their task well. Second, the existing leader should seek ways to keep working culture to improve employees' achievement. Third, the existing leader should move fast in solving the employees' problem in work and be cooperative in hearing aspirations from employees, to create good and conducive relation between leader and subordinate. Fourth, the existing leader should give positional allowance which has not been given to employees, and apply policy to give salary in accordance to the severity of task loaded for employees.

\section{Managerial implication}

The management of PT X Padalarang should do more efforts to improve the quality of managers or supervisors, so they can perform the role and function of leadership more effectively and optimally in company. The efforts that can be done are engaging the leaders of company in manager and supervisor level in leadership training and equipping them with emotional and spiritual quotient, hold by internal company and other institutions. The existing leader should formulate again the policies related to employees' welfare to achieve their job satisfaction during working in company.

\section{Research limitation}

The limitation of this research, considering the result, shows leadership affects job satisfaction about $46,10 \%$ while the rest $53,90 \%$ is affected by other factors, then for the future researchers, they can do a research by adding different free variable $(\mathrm{X})$, like compensation and promotion that can affect employees' job satisfaction. The measurement for leadership and job satisfaction variable can be measured from the respondents' perception about their superior's leadership and their own job satisfaction, so the answer can be biased because those employees tend to evaluate subjectively. For future research, it is expected that the measurement of leadership and job satisfaction variable can use questionnaire that is not only for employees as the respondents, but also for leader or direct superior from the related respondents. 


\section{REFERENCES}

Alam, T.M. (2013). Pengaruh Gaya Kepemimpinan Transformasional dan Budaya Organisasi terhadap Kepuasan Kerja Pegawai (Studi pada Pegawai Kantor Pusat PT Pelabuhan Indonesia III (Persero). Jurnal Administrasi Bisnis, 2(2).

Darwito. (2008). Analisis Pengaruh Gaya Kepemimpinan terhadap Kepuasan Kerja dan Komitmen Organisasi untuk Meningkatkan Kinerja Karyawan (Studi pada RSUD Kota Semarang). Tesis. Semarang: Program Studi Magister Manajemen Program Pascasarjana Universitas Diponegoro.

Djestawana, I.G.G. (2012). Pengaruh Pengembangan Organisasi, Kepemimpinan, Jenjang Karir terhadap Kepuasan Kerja dan Kinerja Pegawai Puskesmas, Jurnal Kesehatan Masyarakat Nasional, 6(6), 261-266.

Fadli, U.M, Hasbullah, R., \& Yulianto, F. (2012). Pengaruh Kepemimpinan Dekan terhadap Kepuasan Kerja Dosen, Jurnal Manajemen, 10(1), 1-14.

Kuncoro, E.A. \& Riduwan. (2007). Cara Menggunakan dan Memaknai Analisis Jalur (Path Analysis). Cetakan pertama. Bandung: Alfabeta.

Kaihatu, T.S., Rini, W.A. (2007). Kepemimpinan Transformasional dan Pengaruhnya terhadap Kepuasan atas Kualitas Kehidupan Kerja, Komitmen Organisasi, dan Perilaku Ekstra Peran: Studi pada Guru-Guru SMU di Kota Surabaya, Jurnal Manajemen dan Kewirausahaan, 98(1), 49-61.

Kondalkar, V.G. (2007). Organizational Behaviour. New Delhi: New Age International (P)Limited, Publishers.

Kristian, M. (2013). Pengaruh Kompensasi dan Gaya Kepemimpinan terhadap Kepuasan Kerja Karyawan Cu Nyai Anta Kabupaten Sekadau, Jurnal Manajemen dan Bisnis, 2(1).

Lahar, H. (2008). Pengaruh Kepemimpinan dan Pengembangan Karir terhadap Kepuasan Kerja Guru SMA di Kabupaten Solok. Tesis. Padang: Program Pascasarjana Universitas Andalas.

Lasya, P.I. (2013). Analisis Pengaruh Kompensasi, Kepemimpinan Atasan, Kesempatan Promosi, dan Lingkungan Kerja terhadap Kepuasan Kerja Karyawan Outsourcing PT Indosat, Tbk, Jurnal Ilmiah Universitas Bakrie, 1(2).

Nugraha, D.P.I.G.A. (2011). Pengaruh Gaya Kepemimpinan dan Motivasi Kerja terhadap Kepuasan Kerja Anggota Detasemen C Satuan III Pelopor Korps Brimob Polri. Tesis. Jakarta: Fakultas Pascasarjana Program Studi Kajian Ilmu Kepolisian Kekhususan Administrasi Kepolisian.

Nurfaiyah., Damajanti, A. (2012). "Pengaruh Motivasi, Kepemimpinan, dan Budaya Organisasi terhadap Kepuasan Kerja dan Kinerja Karyawan PT Samwa Busana Indonesia", Jurnal Solusi, 11(2), 26-42.

Purnomo, H., Cholil, M. (2010). Pengaruh Gaya Kepemimpinan terhadap Kepuasan Kerja berdasarkan Motivasi Kerja pada Karyawan Administratif di Universitas Sebelas Maret Surakarta, Jurnal Manajemen Sumberdaya Manusia, 4(1), 27-35. 
Pratama, C.Y. (2012). Pengaruh Gaya Kepemimpinan Otokratis terhadap Kepuasan Kerja”, Jurnal Sosial dan Industrial Psychology, 1(1).

Ruvendi, R. (2005). Imbalan dan Gaya Kepemimpinan Pengaruhnya terhadap Kepuasan Kerja Karyawan di Balai Industri Hasil Pertanian Bogor, Jurnal Ilmiah Binaniaga, 1(1), 17-26.

Sugiyono. (2006). Statistika Untuk Penelitian. Bandung: Alfabeta.

Sopiah. (2008). Perilaku Organisasi. Yogyakarta: Penerbit ANDI.

Solihin, I. (2009). Pengantar Manajemen. Jakarta: Penerbit Erlangga.

Siregar, D.A. (2012). Pengaruh Kepemimpinan Transformasional dan Kebijakan Kompensasi terhadap Kepuasan kerja dan Hubungannya dengan Organizational Citizenship Behavior (Studi Kasus SMP Swasta Al Ulum Terpadu Medan), Jurnal Ilmiah Abdi Ilmu, 5(1), 767-776.

Saputra, B.M. (2013). Pengaruh Gaya Kepemimpinan Transformasional terhadap Kepuasan Kerja melalui Kepercayaan Karyawan pada Atasan (Studi pada STT, STMIK, STBA, dan Politeknik Cahaya Surya), Jurnal Otonomi, 13(1), 117-126.

Umam, K. (2012). Perilaku Organisasi. Cetakan Kedua. Bandung: CV. PUSTAKA SETIA.

Wilar, A. (2011). Pengaruh Gaya Kepemimpinan Transformasional pada Stres kerja dan Kepuasan Kerja Karyawan bank of Tokyo - Mitsubishi UFJ Cabang Jakarta. Tesis. Yogyakarta: Program Studi Magister Manajemen Fakultas Ekonomika dan Bisnis Universitas Gadjah Mada. 